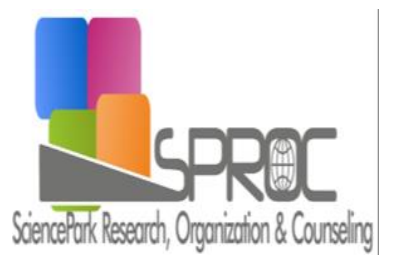

\title{
Municipal Tax Policy as a Tool of Local Development
}

Ladislav Poliak $^{\mathrm{a}}$

Suggested Citation:

Humanities and Social Sciences.

New Trends and Issues Proceedings on

Abstract 
1. Introduction 
2. Data and Methodology

$C_{i}=t^{a} \cdot B_{i}$ 


\section{Potential income $=$ Real income + Tax loss}

\section{Real income $=((\mathrm{NTb} * \mathrm{BR})+\Sigma(\mathrm{NTi} * \mathrm{Ri}))$}

Tax loss $=(\Sigma(\mathrm{NTi} *(\mathrm{BR}-\mathrm{Ri}))+(\mathrm{NTe} * \mathrm{BR}))$

$$
\text { Real income }=((\mathrm{Ab} * \mathrm{BR})+\Sigma(\mathrm{Ai} * \mathrm{Ri}))
$$

$\operatorname{Tax}$ loss $=(\Sigma(\mathrm{Ai} *(\mathrm{BR}-\mathrm{Ri}))+(\mathrm{Ae} * \mathrm{BR}))$ 
social /stabilising function $=\frac{\text { Lass of specified components of real estate tax }}{\text { Potential income of real estate tax }}$

\section{Results and Discussion}

Table 1. The Most Frequented Ways of Social and Stabilizing Functions of Local Taxes Implementation in Slovakia

\begin{tabular}{cccc}
\hline $\operatorname{Tax}$ & Subject to tax & $\begin{array}{c}\text { Social function } \\
\text { implementation }\end{array}$ & $\begin{array}{c}\text { Stabilizing function } \\
\text { implementation }\end{array}$ \\
\hline
\end{tabular}

Real estate tax

Dog licence tax

Tax for use of public space 
Tax for accommodation

Tax for vending machines

Tax for non-winning

gaming machines

Tax for the entry and remaining of the vehicle in historical part of town

Tax for the nuclear device

Table 2. Correlation Matrix - Social Function/Current Deficits

\begin{tabular}{ccccccc}
\hline & Deficit & Deficit & Deficit & Deficit & Deficit & Deficit \\
& 2008 & 2009 & 2010 & 2011 & 2012 & 2013 \\
\hline
\end{tabular}


Table 3. Correlation Matrix - Stabilizing Function/Current Deficits

\begin{tabular}{ccccccc}
\hline & Deficit & Deficit & Deficit & Deficit & Deficit & Deficit \\
2008 & 2009 & 2010 & 2011 & 2012 & 2013 \\
\hline
\end{tabular}




\section{Conclusion}




\section{Acknowledgements}

"Danove prijmy a danova kapacita uzemnych samosprav" Tax revenues and tax capacity of local governments

Scientific Grant Agency of Ministry of Education, Science, Research and Sport of the Slovak Republic and Slovak Academy of Science

VEGA 1/0988/15

\section{References}

Regional Science and Urban Economics, 41,

Regional Science and Urban Economics, 46

Danove pravo na Slovensku

Journal of Public Economics, 118

Teorie regionalniho rozvoje. Nastin, kritika, implikace.

Regional Science and Urban Economics, 37

Journal of Urban Economics, 75

Regionalna ekonómia a politika

Financne pravo.

State and Local Public Finance

Public Finance and Public Policy

Economics, 103

Journal of Public

Podnikanie ajeho komunalna a regionalna podpora 
struktura

Regionalna a urbanisticka ekonomika. Teória lokalizacie a priestorova

Regionalna a urbanisticka ekonomika 2. Regionalny rozvoj a regionalna

politika

McCluskey, W. J. \& Bevc, I. (2007). Fiscal decentralization in the

Republic of Slovenia: an opportunity for the property tax. Property Management, 25, 400-419.

Property Management, 23

Socialna funkcia v pravnej uprave zdanovania prijmov

Public finance in theory and practice

: Economics Letters.

Knowledge for

Market Use 2015: Women in Business in the Past and Present. International Scientific Conference Proceedings.

miestneho rozvoja. Kosice:

Podoby regionalneho a

Ekonomicke aktivity obci a mest

Public finance in theory and practice

Socialna funkcia v pravnej uprave zdanovania prijmov

Regionalna ekonomika a rozvoj

Komunalna ekonomika a politika. Bratislava: 